\title{
« Bank lending networks, experience, reputation, and borrowing costs "
}

\section{$\underline{\text { Auteurs }}$}

Christophe J. Godlewski, Bulat Sanditov, Thierry Burger-Helmchen

Document de Travail n 2010 - 16

Juin 2010

Faculté des sciences économiques et de gestion

Pôle européen de gestion et d'économie (PEGE) 61 avenue de la Forêt Noire F-67085 Strasbourg Cedex

Secétariat du BETA Géraldine Manderscheidt Tél. : (33) 0368852069 Fax : (33) 0368852070 g.manderscheidt@unistra.fr http://cournot2.u-strasbg.fr/beta 


\title{
Bank lending networks, experience, reputation, and borrowing costs
}

\author{
June 2010 \\ Christophe J. Godlewski*^, Bulat Sanditov**, Thierry Burger-Helmchen*** \\ * University of Strasbourg - LaRGE Research Center \& EM Strasbourg Business School \\ ** University of Maastricht, Faculty of Economics and Business Administration\& University of \\ Strasbourg - BETA Research Center \\ *** University of Strasbourg - BETA Research Center \& EM Strasbourg Business School
}

\begin{abstract}
We investigate the network structure of syndicated lending markets and evaluate the impact of lenders' network centrality, considered as measures of their experience and reputation, on borrowing costs. We show that the market for syndicated loans is a "small world" characterized by large local density and short social distances between lenders. Such a network structure allows for better information and resources flows between banks thus enhancing their social capital. We then show that lenders' experience and reputation play a significant role in reducing loan spreads and thus increasing borrower's wealth.
\end{abstract}

Key words: agency costs, bank syndicate, experience, loan syndication, reputation, small world, social network analysis.

JEL Classification: G21, G24, L14.

- Corresponding author. PEGE, 61 avenue de la Forêt Noire, 67085 Strasbourg, France. Tel.: +33(0)368852121. E-mail: godlewski@unistra.fr. 


\section{Introduction}

A syndicated loan is granted by a pool of banks that provide funding to a borrower under a single agreement and lies at the crossroads of relationship and transaction lending (Dennis and Mullineaux 2000). In 2009, more than 1.5 trillion USD of debt has been raised on the worldwide syndicated lending market, representing one third of external financing for companies (Thomson Financial 2009). The benefits of loan syndication both for lenders (portfolio risk and sources of revenues diversification) and borrowers (mostly lower costs as compared to bond issues or a series of bilateral loans) largely explain the success of syndicated lending. However, syndicated loans have their drawbacks because the organization of a syndicate of banks may expose its members to the adverse consequences of informational frictions and potential agency costs.

Important features of syndicates that gain in recent academic interest for their potential mitigation effect of agency costs are lenders' experience and reputation. Indeed, as the arrangers are responsible for due diligence, allocation of the loan to other syndicate members, and ex post monitoring, banks in the syndicate will often rely on the leaders' reputation in making lending decisions (Ross 2010). Hence, reputable and experienced leaders can enhance monitoring and the ability to attract participants, help show the quality of the borrower and the deal, and reduce agency costs (Gatti et al. 2008; Panyagometh and Roberts 2010).

Lender's experience and reputation are closely related to trust and reciprocity which represent critical forms of social capital (Song 2009), in particular for teams (Carpenter et al. 2009). Social capital can be considered as the foundation of every economic transaction because it enables exchange given that contracts are incomplete and allows transaction costs to be reduced (Arrow 1974). Social networks are considered as fundamental drivers of social capital (Di Cagno and Sciubba 2010) and syndicated lending market bears several social network features because it serves as an information network which allows the acquisition of private information on borrowers' quality and as a capital network which allows the raising of the necessary funding of loans (Baum, Shipilov, and Rowley 2003; Baum, Rowley, and Shipilov 2004; Morrison and Wilhelm 2007). Moreover, recent empirical evidence by Champagne and Kryzanowski (2007), Cai (2010), and Cai, Saunders, and Steffen (2010) show that collaboration and reciprocity are important features of bank loan syndication as reciprocal arrangements among syndicate arrangers appear to be a very common practice leading to choose banks having similar lending expertise.

In this article, we provide an in depth empirical investigation of the role of syndicate lenders' experience and reputation for loan syndication using social network analysis. We first analyze the small world properties of the syndicated lending market. A small world is a locally dense social network where social distances between actors are short. Such a network improves market efficiency 
as it allows larger information and resource flows. It can also develop reciprocity and trust between lenders and thus enhance the formation of social capital, ultimately increasing lenders' experience and reputation. Hence, syndicated lending small world may provide benefits in terms of resource procurement and the reduction of information asymmetry. This in turn can mitigate agency costs and lower borrowing costs. Thus, we evaluate the sensitivity of loan pricing to lenders' experience and reputation, proxied by network centrality measures of banks.

We contribute to the developing literature dealing with small world features of financial intermediation (Allen and Babus 2008), by providing an empirical description of the organization of the syndicated lending market. Such a "big picture" gives a better insight into the complex characteristics and dynamics of the interactions between lenders. We also contribute to the literature investigating the role of banks' experience and reputation in financial transaction processing (Ross 2010), with a particular focus on their role in mitigating informational and agency costs stemming from the particular features of bank loan syndication. We thus provide additional empirical evidence on the impact of syndicate experience and reputation on borrowing costs and thus on borrower wealth.

The rest of the article is organized as follows. We describe the loan syndication process and its potential agency problems and survey relevant literature on social network analysis of financial intermediation in section 2. Section 3 is devoted to the description of data and of the social network analysis methodology. Results are displayed and discussed in section 4. Finally, section 5 concludes the article.

\section{Syndicated lending and social networks}

This section is devoted to the description of the loan syndication process, the related agency costs and the role of lenders' experience and reputation on the syndicated lending market. Then, we provide a survey of the recent literature on social networks analysis applied to financial intermediation.

\subsection{Syndicated lending and agency costs}

The transaction process of bank loan syndication can be divided into three main stages ${ }^{1}$. During the pre-mandated stage, after soliciting competitive offers to arrange the syndication from one or more banks (usually the main relationship banks), the borrower chooses one or more arrangers that are mandated to form a syndicate and negotiates a preliminary loan agreement. The syndication can either involve a sole mandate or a joint one, the latter implying the participation of more than one

\footnotetext{
${ }^{1}$ See Esty (2001) for a detailed presentation of the bank loan syndication process.
} 
lead bank. Such syndications are usually chosen by the borrower in order to maximize the chances of achieving the desired loan syndication. The arranger is responsible for negotiating the key loan terms with the borrower, appointing the participants and structuring the syndicate.

During the post-mandated stage, the arranger prepares a documentation package - called an information memorandum - for potential syndicate members, containing information about the borrower's creditworthiness and the loan terms. The arranger largely determines the initial set of potential participants to target, and factors such as previous experience with the borrower and/or the arranger, in the industry sector or the geographic area, are strong drivers for being chosen by the arranger to join the syndicate. The presentation and discussion of the content of the information memorandum, as well as the announcement of closing fees and the establishment of a timetable for commitments and closing are done during a road show. Then, the arranger sends formal invitations to potential participants and determines the allocation for each participant.

Finally, the operational post-signing stage takes place after the completion date when the deal becomes active and the loan is operational, binding the borrower and the syndicate members by the debt contract.

The syndicated loan transaction process is heavily dependent upon the arrangers because of their pivotal role in structuring the deal, negotiating the terms of the loan agreement, and organizing the syndicate. However, the success of the syndication process is a function of negotiations and information flows between all the parties involved in the transaction: borrower, arrangers, and other syndicate members. Therefore, the fact that loan syndication involves several actors and is a complex process involves specific agency costs which can increase borrowing costs and thus are harmful for borrower's wealth.

First, private information about the borrower can create adverse selection problems, as the arranger may be inclined to syndicate loans for unreliable borrowers. However, such an opportunistic behavior can damage the arranger's reputation, having a negative impact on the success of future syndications (Pichler and Wilhelm 2001). Hence, this "threat of reputation loss" can serve as a disciplining device of the arranger's behavior. Second, participating banks may delegate monitoring to the arranger, but the banks are not in the loop as to what the arranger is doing, which might result in situations of moral hazard. In addition, the arranger has less incentive to monitor the borrower than if it were to lend the full amount of the loan (Pennachi 1998). Third, the borrower's financial distress is an important factor in syndication as it is more complicated to reorganize and reformulate the agreement for the borrower because a collective decision needs to be taken by the lenders (Bolton and Scharfstein 1996).

Recent empirical evidence shows that adapting the organizational structure of a syndicate is a crucial feature in mitigating the agency costs of syndication which stem from the fact that different 
syndicate members have access to different degrees of information. In particular, syndicate characteristics such as lenders' interactions, experience, and reputation can mitigate syndication agency problems ${ }^{2}$.

Previous relationships between syndicate members can help to alleviate informational frictions and agency costs of syndication. Indeed, repeated interactions over time directly aim at solving problems of informational asymmetries because they create trust and reciprocity. Hence, prior relationships between syndicate members have a significant impact on the probability of syndicating a deal together (Champagne and Kryzanowski 2007). These relationships are often reciprocal arrangements in the sense that lenders maintain stable relationships between them and rotate their roles in subsequent joint syndications (Cai 2010). Moreover, Cai, Saunders, and Steffen (2010) find that lead arrangers tend to choose participants having a close lending expertise in terms of borrower industry or geographic location.

Furthermore, as the arrangers are responsible for due diligence, allocation of the loan to other syndicate members, and ex post monitoring, banks in the syndicate will often rely on the leaders' reputation in making lending decisions (Ross 2010). Therefore, reputation is an important aspect for syndicated lending (Gopalan, Nanda, and Yerramilli 2007), because reputable and experienced leaders can enhance monitoring and the ability to attract participants, help show the quality of the borrower and the deal, and reduce agency costs (Gatti et al. 2008; Panyagometh and Roberts 2010). Approval from experienced, reputable and prestigious arrangers actually creates economic value by reducing the overall costs of syndicated loans.

Recent empirical evidence tends to conclude that loan pricing is sensitive to information costs of syndication (Focarelli, Pozzolo, and Casolaro 2008; Ivashina 2009) and lead banks reputation is found to be a crucial feature for the success of syndication but its impact on loan pricing is mixed. On the one hand, if lead banks' reputation act as a certification device reducing adverse consequences of information asymmetry within the syndicate, loan spreads can be lower especially when informational frictions are expected to be severe (Gatti et al. 2008; Ross 2010). Regarding the foundation of experience or reputation, i.e. reciprocity, results provided by Cai (2010) also show that loans arranged in a reciprocal way are less costly for borrowers. Similar results are obtained by Cai, Saunders, and Steffen (2010) for syndicates composed of arrangers which are closer in terms of lending expertise. On the other hand, McCahery and Schwienbacher (2010) find that loans arranged

\footnotetext{
${ }^{2}$ Other characteristics such as syndicate size and concentration also have an influence on agency costs (see Esty and W.L. Megginson 2003; Lee and Mullineaux 2004; Jones, Lang, and Nigro 2005; François and Missonnier-Piera 2007; Sufi 2007; Godlewski 2010). ${ }^{3}$ We consider as lead banks syndicate members bearing the following titles: administrative agent, agent, arranger, bookrunner, lead arranger, mandated arranger, senior arranger, underwriter, lead bank, joint arranger, managing agent, senior managing agent, syndication agent, co-agent, co-arranger, senior co-arranger, sub-underwriter, co-lead arranger, co-syndication agent, counderwriter.
} 
by reputable banks lead to higher loan spreads, especially for opaque borrowers who pay a "reputation premium".

Lenders' experience and reputation are related to their social capital, the critical elements of which are trust and reciprocity. These features are seen as fundamental because they enable the reduction of transaction costs (Arrow 1974), which, in the case of a syndicated loan, are strongly related to agency costs. Social capital features such as interaction, reciprocity, and trust are driven by social networks (Di Cagno and Sciubba 2010) and syndicated lending markets exhibit many social network features because they serve as information and capital networks (Baum, Shipilov, and Rowley 2003; Baum, Rowley, and Shipilov 2004; Morrison and Wilhelm 2007).

\subsection{Network analysis of financial intermediation}

The linkages between financial institutions can be captured by using a network representation of financial systems. The general concept of a network is intuitive: it describes a collection of nodes and the links between them. The notion of nodes is fairly general: they may be individuals, firms or countries. A link between two nodes represents a direct relationship between them.

Recently, Pistor (2009) provides an integrated approach looking at financial system from a global perspective. Network-finance is a critical institutional arrangement when there is great uncertainty about financing choices for which inter-firm relations come in different forms and intensity. The concept of "strategic alliances" depicts a lose affiliation of firms and can be defined as "voluntary arrangements between firms involving exchange, sharing, or co-development of products, technologies or services" (Gulati 1998). According to this definition, any relation among independent entities that involves collaborative efforts without fully allocating control rights to one member in the alliance over another can be regarded as an alliance. Strategic alliances have become prominent in industries marred by uncertainties, such as banking. Networks resemble alliances in the sense that they are relatively loose configurations and typically lack a common governance structure. Networks understood as governance devices for cooperative relations can facilitate the expansion of economic activities.

However, the literature on financial networks is still at an early stage (Allen and Babus 2008). Cohen, Frazzini, and Malloy (2008) investigate information transfers in security markets and find that mutual fund portfolio managers place larger bets on firms they are connected with through their networks, and perform significantly better on these holdings relative to their non-connected holdings. These results suggest that social networks are an important mechanism for information flows. Morrison and Wilhelm (2007) argue that investment banks exist because they create networks. These financial institutions mainly issue and underwrite securities and these activities 
require the development of two networks: an information network which allows the acquisition of information about the demand for an issue, and a liquidity network to provide the funds to purchase the securities. Indeed, Schnabel and Shin (2004) document how in the eighteenth century networks of merchant banks allowed capital accumulated in one part of Europe to be invested in far distant parts. These networks compensated for asymmetric information due to distance and also provided the necessary capital.

Baum, Shipilov, and Rowley (2003) and Baum, Rowley, and Shipilov (2004) are the rare authors to apply social network analysis to investigate Canadian bank syndicates. They argue that the importance of understanding small world structures stems from their efficiency in moving information, experience, and other resources that enable organizational learning, adaptation and competitive advantage. External interdependence in the face of transaction costs is the most common explanation for the emergence of interfirm networks. This interdependence focuses on two main considerations: resource procurement (loan portfolio diversification and regulatory capital requirements limits) and uncertainty reduction (expertise and information of syndicate members). Hence, relations are built to share the costs and risks of undertaking large-scale projects, to develop existing markets or enter new ones, to pursue resource specialization, or to mitigate competition. Such objectives make firms interdependent with other firms that possess the capital, knowledge, complementary assets, and technical capabilities.

Social network analysis is also applied to study venture capital (VC) finance. Kogut, Urso, and Walker (2007) provide an extensive analysis of the US VC syndication market over a 40 year period. They focus in particular on the dynamics and complexity of the network and show the rapid emergence of a national network of syndications. Hochberg, Ljungqvist, and Lu (2007) examine the influence of VC networking when syndicating their portfolio company investment on the performance of VC firms in US. They find that better-networked VC firms have better fund performance and that the portfolio companies of better networked VCs are more likely to survive subsequent financing and eventual exit. This implies that one's network position should be an important strategic consideration for an incumbent VC, while presenting a potential barrier to entry for new VCs. Finally, Meuleman et al. (2009) examine the influence of the network position of a private equity investor on the relationship between agency costs and the decision to syndicate on the UK private equity market. They find that the network position of an investor alleviates the negative impact of agency costs on the syndication decision.

Overall, recent but scarce evidence shows that financial market networks play an important role in organizing and shaping transactions, reducing informational frictions, and ultimately affecting performances of actors (lenders and borrowers) on these markets. 


\section{Data and methodology}

In this section we describe the data and the social network analysis methodology. We especially focus on the definition of a network and of its most important characteristics.

\subsection{Data}

Syndicated loans in Europe account for a third of the worldwide syndicated lending market. A recent loan of 20 billion USD for the French company EDF was ranked as $3^{\text {rd }}$ top deal (ThomsonFinancial 2009), while the French bank BNP Paribas was among the top 10 bookrunners in terms of proceeds and underwritten volume. Furthermore, corporate financing through syndicated loans has gained in importance as it represents more than $10 \%$ of private credit in France. It is also worth noticing that bank syndicates lending to French companies exhibit some particular features as they are larger and less concentrated as compared to syndicates in the US or the UK (Godlewski 2009). These particular characteristics of the lending syndicates and the importance of syndicated loans in financing companies provide us with a pertinent empirical framework with respect to the aim of this article. Indeed, the presence of numerous lenders in the syndicates can signal an important level of social interactions which may serve as drivers of banks experience and reputation. This in turn may affect the syndicated lending market organization and development.

Data on the French syndicated lending market, including detailed information on the loan agreement and bank syndicate characteristics, come from the Dealscan database (LPC, Reuters). This database is commonly used in empirical studies on syndicated lending (Champagne and Kryzanowski 2007; Sufi 2007; Ivashina 2009; Ross 2010). We are able to identify the country, name, and role of 436 lenders that have participated in 924 syndicated deals to 776 French companies from 1992 to 2006. For each deal we have access to information on the loan amount, spread, maturity, guarantee, covenants, type, and purpose. We also have information on the size, concentration and composition of the banks syndicate.

The main descriptive statistics and definitions of variables are provided in Table 1 while Table A (in appendix) displays the distribution of lenders' countries in the sample. We remark that the average loan size is close to 2 billion USD with a 120 bps spread over the benchmark rate (such as Libor) and a maturity of almost 6 years. Loans are rarely guaranteed and only 1 out of 10 has financial covenants. More than 1 out of 3 loans are for debt repayment purpose while the types of loans are relatively balanced between term and revolving loans.

We also observe that an average syndicate is composed of 14 lenders with more than 5 arrangers. The presence of French banks is important as they represent $40 \%$ of an average syndicate. Apart from France, lenders come from 40 different countries but most of the remaining banks are 
from Germany, US, Japan, UK, the Netherlands, and Italy. The concentration of the loan shares retained by arrangers is rather low, just above $10 \%$. The presence of reputable lenders (listed on the League Table by Reuters) is relatively important, equal to $34 \%$. This figure drops to less than $15 \%$ if we focus on the reputable French lenders only.

The most important industry sectors of the borrowers are Manufacturing (36\%), Transport, Communication and Electricity (15\%), Finance and Insurance (14\%), Construction (7\%), Wholesale Trade (7\%), and Retail Trade (6\%).

\subsection{Network definition and characteristics}

Information on banks' participation in syndicated loans (or deals) provides us with an input to construct an "affiliation network". In social network analysis, an affiliation network is a two-mode (bipartite) network with two types of nodes: actors linked with events in which they participate. In our case, actors are banks, events are syndicated deals and ties connect banks with the deals in which they participate. A hypothetical example of a bipartite network is shown in Figure 1 (a). Connectivity in such a network is achieved through banks participating in several syndicates, such as lenders 4 and 8 in Figure 1 (a).

Affiliation networks rarely become an object of study themselves but rather are used for constructing the corresponding social networks of actors. To make a projection of the bipartite network of syndicated deals we follow Baum, Shipilov, and Rowley (2003) who re-construct banks' network by accounting only for the relationships between lead - participant banks. Indeed, banks participating in the same syndicate typically have minimal contacts and their interactions are primarily with lead banks ${ }^{3}$ (Rhodes 2004).

Further, we assume that ties between lead banks and other syndicate members do not disappear immediately, but remain active for several years. Hence, we use overlapping moving fiveyear windows following Baum, Shipilov, and Rowley (2003). Thus, for each of the time windows we construct lenders' networks considering only the syndicated loans arranged during these periods. We obtain 14 moving windows over the 1992-2006 time span, the first going from 1992-1995 and the last from 2002-2006.

An illustration of how a bipartite network can be projected to a one-mode network is displayed in Figure 1 (b). With this illustrative network, we can introduce several network measures needed to characterize a syndicated lending market.

\footnotetext{
${ }^{3}$ We consider as lead banks syndicate members bearing the following titles: administrative agent, agent, arranger, bookrunner, lead arranger, mandated arranger, senior arranger, underwriter, lead bank, joint arranger, managing agent, senior managing agent, syndication agent, co-agent, co-arranger, senior coarranger, sub-underwriter, co-lead arranger, co-syndication agent, co-underwriter.
} 
A path between a pair of lenders $i$ and $j$ is a sequence of lenders beginning with lender $i$ and ending with lender $j$ such that each lender in this sequence is unique and has ties with lenders preceding and following him in the sequence. Two lenders are connected if there is a path between them. The length of a path is the number of steps ("edges") separating one from the other. Distance between two lenders is defined as the length of the shortest path (called "geodesic") connecting them. Further, a connected component is a subset of nodes (lenders) such that any two nodes from this subset are connected. An isolate is a component which consists of a single node.

For instance, on Figure 1 (b), lenders 1 and 10 are connected because there are several paths between them, e.g. through lenders 2, 4, 5, 7 and 8. The corresponding geodesic, or shortest path from 1 to 10 , is $(1-2-4-8-10)$ which has length 4 . This network has two components $\{1 \div 10\}$ and $\{11\}$. Lender 11 is an isolate as it is disconnected from the rest of the network.

A generic feature of social and economic networks which has received much attention in the recent years is "small world" structure (Uzzi, Amaral, and Reed-Tsochas 2007). Most social networks are locally dense, but at the same time the social distances between the actors are relatively short. This property can be quantified using notions of clustering coefficient and average path length. Average path length is defined as the mean of the distances between all pairs of actors in a network and measures how close the actors in the network are. The shorter the average path length the faster and more efficient the information or resources may flow between two distant parts of the network. The clustering coefficient of an actor (lender) is the share of the actor's neighbors who have direct contacts with each other.

For instance, on Figure 1 (b) lender 2 has clustering coefficient equal to 0 because none of his contacts (lenders 1,3 and 4) have direct links with each other. Lender 6 has four contacts (lenders 4, 5, 7 and 8) which makes 6 pairs of which only one pair (lenders 4 and 7) does not have direct contact, hence the clustering coefficient of lender 6 is $5 / 6$.

In a social network with high average clustering, "friends" of my "friends" are likely to be my "friends", thus such a network is abundant with the closed triangle ${ }^{4}$. Such network structures with many alternative paths through which the information or resources can flow between actors allow efficient social control alleviating the problems of opportunistic behavior and supporting reciprocity, trust and social norms (Coleman 1988). These are important characteristics to reduce informational frictions and agency costs in financial transactions such as syndicated loans.

Many real world networks are "small worlds": they are sparse, have short average path length and are highly clustered. Watts and Strogatz (1998) showed how such structures may emerge when a network composed of tightly knit clusters only marginally linked with each other (thus having

\footnotetext{
${ }^{4} a$ has a contact with $b, b$ has a contact with $c$, but $c$ also has contact with $a$ closing the triangle $a b c$.
} 
high clustering and long average path length) is transformed by randomly rewiring only a small fraction of links in the network. Their model is based on the fact that random rewiring creates shortcuts between otherwise distant parts of the network and while the average distance is highly responsive to the presence of shortcuts, the local structure (high clustering) is not. Consequently, if the share of the rewired links is small, a network has both short distances and high clustering.

To examine whether an observed network is a small world, one compares it with a benchmark random network. Following Watts and Strogatz (1998), most empirical studies compare the average path length $\left(L_{a}\right)$ and clustering coefficient $\left(C_{a}\right)$ of the observed networks with corresponding characteristics of an Erdos-Renyi (ER) random graph, where the same number of actors is randomly connected by the same number of links as in the observed network.

While ER random graph may be a fair benchmark network for many social networks, in case the network was reconstructed from an affiliation network comparison with ER may be misleading (Newman, Strogatz, and Watts 2001). Indeed, making a projection of a two-mode network of teams and actors onto the set of actors, one has to assume certain structures of relationships within a team, thus teams will be represented by subgraphs of a fixed non-random structure. Therefore comparison of resulting one-mode network with a random graph where any link, including withinteam links, may lead to wrong conclusions (Uzzi, Amaral, and Reed-Tsochas 2007).

To circumvent this problem, we construct benchmark random network as a projection of randomly rewired two-mode lender-deals network (rather than rewiring one-mode projections to obtain ER random graphs) as follows. First, we randomly reconnect deals and lenders in the observed network controlling that (a) each lender in the rewired network participates in the same number of deals as in the observed network, (b) each deal has the same number of lenders as in the observed network, and (c) each deal has the same number of arrangers as in the observed network ${ }^{5}$. The resulting random two-mode network is projected onto the set of lenders. For each of the 14 observed moving time windows, we simulate 100 random networks and determine their structural properties. The average distance $\left(L_{r}\right)$ and clustering $\left(C_{r}\right)$ averaged over 100 simulation runs are presented in columns $L_{r}$ and $C_{r}$ of the Table 2 along with the average distance $\left(L_{e r}\right)$ and clustering $\left(C_{e r}\right)$ of corresponding ER random graphs, as a robustness check.

\subsection{Individual characteristics within networks}

We now turn to the definition of the characteristics of lenders' individual positions within the syndicated lending network. We focus on several measures of actors' importance: degree, closeness

\footnotetext{
${ }^{5}$ Here we assume that the bank's role (lead or participant) does not depend on the bank's identity. Alternatively, one can also take into account that some banks become arrangers more often than others and control for the number of deals in which the given bank is an arranger.
} 
and betweenness centralities. These measures serve as proxies of lenders' experience and reputation on the syndicated lending market.

Actor's degree or degree centrality, $C_{D}$, can be defined as the number of the closest neighbors, the set of actors with which the focal actor has direct links. Degree centrality characterizes the involvement of an actor in social relationships. It is a local measure, as it does not depend on the configuration of the whole network except the local neighborhood of the actor. Beside the simple definition of $C_{D}$ commonly used in many empirical studies, there is also a standardized version of the degree centrality, which takes into account that the same number of relationships in a small network is not exactly the same as the same number of relationships in a larger network. The standardized version of degree centrality is defined as:

$$
C_{D}^{\prime}=\frac{C_{D}}{n-1}
$$

where $n$ is the size of the network (the number of actors in the network). Obviously, standardization has no effect on analysis if centrality scores are compared among the agents in the same network.

Closeness centrality measures actor i's position in a network in terms of his proximity to other actors. It is defined as an inverse of the sum of the social distances between the actor and other ( $n-1)$ actors in the network (normalized by the size of the network):

$$
C_{C}=\frac{n-1}{\sum_{j \neq i} d(i, j)}
$$

where $d(i, j)$ is the distance between actor $i$ and $j$. Closeness centrality conveys the intuitive understanding of the centre of a network. The closer the actor to the centre of the network, the higher his closeness centrality score ${ }^{6}$.

Finally, betweenness centrality measures how well the actor is positioned with respect to control over the flow of information or other resources in the network. Betweenness centrality of actor $i$ can be defined as the ratio of the shortest paths between all pairs of actors in the network which passes through the actor (deflated by the number of alternative shortest paths):

$$
C_{B}=\frac{2}{(n-1)(n-2)} \sum_{j<k} \frac{g_{i}(j, k)}{g(j, k)}
$$

where $g_{i}(j, j)$ is the total number of the shortest paths between actors $j$ and $k$ and $g(j, j)$ is the total number of the shortest paths between actors $j$ and $k$.

\footnotetext{
${ }^{6}$ Imagine a star network where one node occupies the centre to which all other $(n-1)$ actors are connected and no ties exist between peripheral actors (e.g. a deal with one lead bank and ( $n-1)$ participant banks). Then closeness centrality of the star is 1 , while for the other actors closeness centrality is $1 /(2 n-3)$.
} 


\section{Results}

We present and discuss in this section the results on the organization and structure of the French syndicated lending network and the influence of lenders' individual network characteristics on the cost of bank loans for borrowers.

\subsection{Small world}

Results for the French syndicated lending network for each of the 14 overlapping time windows are displayed in Table 2. We first remark that as raising capital through syndicated loans became more and more important over the period under investigation, the number of deals (column deals) has been continuously increasing as well as the number of lenders (column lenders) albeit at a lower rate for the last indicator. We observe that there were 82 deals and 166 lenders involved during time window 1 and 494 deals and 347 lenders involved during time window 14. Peaks are observed for window 13 (years 2002-2006) with 577 deals and 392 lenders. Due to the increased number of deals and involved lenders, the number of links (column links) has been multiplied by 10 , starting at 679 during time window 1 to reach 6634 during time window 14, for a peak in window 13 with 8151 links.

Regarding network characteristics, a remarkable feature of the French syndicated lending network is its high connectedness as isolates (column isolates) comprise less than $5 \%$ of all lenders for most periods. Furthermore, the largest connected component $(L C)$ consists of more than $90 \%$ of all lenders. Therefore when studying the properties of the network we can focus solely on the largest component without loss of information.

To see how the average distance and clustering of the actual networks $\left(L_{a}\right.$ and $\left.C_{a}\right)$ differ from the corresponding characteristics of the benchmark random networks constructed with the simulation $\left(L_{r}\right.$ and $\left.C_{r}\right)$, we calculate $\mathrm{LL}$ ratio $\left(L_{a} / L_{r}\right)$ and $C C$ ratio $\left(C_{a} / C_{r}\right)$. In the model of Watts and Strogatz (1998) the small worlds emerge when CC ratio is many times greater than 1 , while LL ratio is close to 1 . To quantify the small world characteristics of our networks, we also calculate the "small world ratio" SW = CC / LL (Davis, Yoo, and Baker 2003; Uzzi and Spiro 2005).

We first discuss results obtained with the simulated benchmark random network method, to comment later on results obtained with the ER method. In our network, LL ratio stays close to 1 for all periods. However, although the CC ratio is above 1 for most of the periods, it is generally not very different from 1. The SW is relatively low in comparison with the values of Watts and Strogatz (1998) model. However, it should be emphasized that the choice of the benchmark random graph may in general imply different values of the SW at the small world phase transition.

Although the relatively small values of SW ratio do not allow us to unambiguously assert that the French syndicated lending network has small world properties, the dynamics of the CC, LL and 
SW ratios displayed in Figure 2 (A) clearly indicates that the network becomes "small worldish" over time. Indeed, as the network expands the rate at which the normalized clustering ( $\mathrm{CC}$ ratio) grows outpaces the growth of the normalized average distance (LL ratio), therefore SW as the ratio of the two is growing over time. At the beginning of the observation both CC ratio and LL ratio are below 1 . The fact that the clustering and distances in the observed network are lower than in a corresponding random network stems from certain regularities in the actual network.

A subgraph representing a single deal has a star-like structure, where the centre is occupied by lead banks and the "rays" are participant banks (see Figure 1 (b): separate deals are shown by red circles). Since the benchmark random graphs preserve the structure of deals (the number of participants and the number of lead banks), the random networks consist of the identical set of starlike subgraphs assembled in various ways. Indeed, the number of deals for each of the lenders was kept the same as in the actual network. The structural properties of the assembled networks depend on the identities of the active banks which connect the deals, more precisely on the roles played by active banks in the respective syndicates, i.e. whether they are ordinary participants or lead banks.

When deals are connected via an ordinary participant of the two deals, the resulting network will have longer social distances and lower clustering than if the deals were connected via a lead bank. In the former case, the distance between participants of the two deals (excluding the connecting participant) is 4 , while in the latter it is 2 . As for clustering, it should first be noticed that when two deals are connected, only clustering coefficients of all but the connecting bank stay the same as they would if the two deals were disconnected. The change in the clustering coefficient of the connector depends on the number of direct links it has in the two deals. The higher it is, the more "open triangles" the resulting network has and the less is the clustering. Since lead banks have more connections, networks where deals are connected via leaders have lower clustering.

Since in the simulations we control for the number of deals in which each lender participates, but not for the number of deals in which it has been lead bank, the fact that clustering and average path length in the actual networks are lower than in the random benchmark networks suggests that in the actual networks subgraphs corresponding to the deals are disproportionally more likely (in comparison with the pure chance) to be connected through lead banks than through participant banks. That may happen when there is a core of banks specializing in syndicated loans, while participant banks are less likely to participate in many deals with different arrangers ${ }^{7}$.

By contrast, at the end of the observation period, both CC and LL ratios are above 1 pointing to the fact that now the network is more likely to be connected by the participants. This brings us back to the idea of small worlds. A network connected by lead banks is likely to be highly centralized

\footnotetext{
${ }^{7}$ For instance, three large banks (JP Morgan Chase, Bank of America, and Citigroup) control over half of the U.S. commercial loan market by volume through the syndication process (Ross 2010).
} 
with a dense core occupied by leaders and periphery consisting of participant banks. By contrast, a network where connections are done through participants may be less centralized and the core may have several dense parts populated by lead banks which are connected through participant banks. In this respect participant banks may play a similar role as the "shortcuts" in Watts and Strogatz (1998) model.

To complete the analysis, let us compare our results with what we would have found had we used ER random graphs as benchmark. The last three columns of Table 2 report average distance $\left(L_{e r}\right)$, clustering coefficient $\left(C_{e r}\right)$ and small world ratio $\left(S W_{e r}\right)$ for ER random graphs with the number of banks and links between them as in the observed networks. First, ER random networks are significantly less clustered (almost the order of the magnitude) than the observed networks which owes to the fact that the ER does not account for the observed networks being projections of twomode networks. Average distances, however, are not very different from the distances in the observed network. As a result, the small world ratio, mostly driven by the ratio of clustering coefficients, is a fairly large number above 10 . Thus had we used ER as a benchmark we might have unambiguously concluded that the French syndicated network is a small world. However, our analysis demonstrates that the matter is more subtle here. Our results suggest that the syndication network becomes "small worldish" with time (see the dynamics of the small world ratio at Figure 2 (A)). The dynamics of CC, LL and SW ratios based on ER random graph presented at Figure 2 (B) does not show any particular pattern.

Overall, we can claim that the dynamics of the French syndicated lending market tends to confirm that over time the networks of lenders become small worlds in the sense of Watts (2003). This particular feature has important implications for the flows of information between lenders and their level of social capital which ultimately influences lenders' experience and reputation. This in turn can affect informational frictions and agency costs of syndication, and impact the borrowing costs.

\subsection{Impact of individual network characteristics on loan spread}

We investigate the influence of individual network characteristics of banks syndicating loans for French borrowers on the loan spread. The latter is the main loan contract characteristic which influences the cost of debt and ultimately the company cost of capital. We claim that greater centrality of syndicate members indicates a higher level of social capital acquired through interaction, reciprocity, and trust. This in turn increases their experience and reputation allowing the mitigation of informational frictions within the syndicate and affecting borrowing costs.

We perform series of regressions of the loan spread over the benchmark rate (such as Euribor or Libor) on the syndicate average lenders' betweenness, closeness and degree centralities. 
Betweenness is a measure of the lender's position in the network and his control over network flows. This particular feature is the most important in mitigating information asymmetries because it takes the network's intermediation position of the lender into account. Closeness measures the lender's distance to the network center, i.e. the closer a lender is to the network center, the better his access to information and resources flows. Degree is a local measure of lender's involvement in social relationships. Univariate statistics for these measures are displayed in Table 1.

We evaluate the impact of each measure of centrality on the loan spread separately using six different specifications. We employ OLS regressions with standard errors clustered at the syndicated loan level ${ }^{8}$. The benchmark specification controls for the main loan characteristics such as loan amount, maturity, the presence of guarantors and covenants, following notably Focarelli, Pozzolo, and Casolaro (2008) and Ivashina (2009) ${ }^{9}$. Each subsequent specification includes separately a specific syndicate characteristic: the number of lenders, the percentage of local lenders, syndicated loan concentration, the percentage of league table lenders and local league table lenders ${ }^{10}$. These specifications aim at controlling for other syndicate characteristics that may mitigate informational frictions and agency costs of syndication, such as the presence of better informed local lenders, more concentrated holdings of the loan which reduce moral hazard, or banks listed on League Tables. The estimated equation can be summarized as follows:

\section{Loan spread $=f($ Syndicate centrality, Other syndicate characteristics, Controls $)$}

Results are displayed in Tables 3, 4, and 5 for betweenness, closeness, and degree centrality measures respectively. A correlation matrix for all variables is provided in Table B (in appendix). We first remark a satisfactory statistical quality of the regressions as the $\mathrm{R}^{2}$ is close to $50 \%$ and the Fischer statistic is always significant for every specification in Tables 3 to 5 . Next we observe that all three syndicate centrality measures exhibit significant and negative coefficients in a vast majority of specifications ${ }^{11}$. The strongest results are obtained for the betweenness centrality measure as its coefficient is always negative and significant in Table 3. Hence, in 8 cases out of 12 we are able to

\footnotetext{
${ }^{8}$ Similar results are obtained when clustering at the borrower or lender level.

${ }^{9}$ Some of the loan characteristics can be endogenous such as the loan spread and amount. Unfortunately, we do not have enough information to build instrumental variables to perform multi stage regressions. However, to check if potential endogeneity could drive the results, we have also performed separate regressions adding step by step one loan variable to the benchmark specification, as well as trying different combinations of the loan characteristics variables. This procedure does not alter the coefficients of the syndicate centrality measures or the coefficients of other loan variables.

${ }^{10}$ Although not always statistically correlated, these syndicate characteristics are expected to be economically related therefore we do not include them all at the same time in a single specification. Sample size is strongly reduced for regressions with the Syndication concentration variable because of missing information regarding the retained shares of the loan by arrangers.

${ }^{11}$ Exceptions are models (2.4), (2.5), (2.6), and (3.5).
} 
validate the benefit of a central syndicate in funding a loan in terms of reduced loan spread and thus borrowing costs. In other words, borrowers can gain from reduced loan spreads when they are funded by syndicates composed of lenders that are more central on the syndicated lending market. Hence, lenders' social capital matters for loan syndication as the presence of such experienced and reputable lenders having access to greater amount and flows of information and resources serves as a device mitigating informational frictions and agency costs related to loan syndication. This is shown to be beneficial for the borrowers in terms of a reduced loan price.

We further notice interesting effects stemming from other syndicate characteristics that may reduce information asymmetry and agency problems. First, we remark that the presence of local lenders or a concentrated syndicate do not have any significant influence on the loan spread or on the impact of syndicate centrality on the loan spread. The only two syndicate features that have a significant and negative influence on the borrowing costs are the presence of league table lenders and local league table lenders. This result is coherent with the signaling role of lead bank reputation in reducing the costs of information asymmetries. Furthermore, we observe that in these cases, the coefficients of the centrality measures are reduced in magnitude, especially for the betweenness measure. However, their significance is not altered, except for the closeness and degree centrality measures ${ }^{12}$. Hence, league table reputation appears as an important syndicate feature to reduce loan spread but not enough to vanish away the more important effect of syndicate betweenness centrality.

Finally, we remark that among loan characteristics, only loan amount and maturity bear significant coefficients which remain robust across most of the specifications. Loan size has a negative impact on loan spread for economies of scale reasons while longer maturities are positively related to borrowing costs because of greater risk.

We also perform robustness checks of our results by using the same specifications but on sub-samples characterized by the presence of local lenders only, large loans, long maturities, large syndicates, concentrated syndicates, numerous league table lenders and local league table lenders. The classification of deals is done on the basis of the median of the relevant variable. Hence, we aim to isolate syndicated deals that are more or less informational problematic. For instance, the exclusive presence of (better informed) local lenders or numerous league table banks should reduce information asymmetry and agency costs, so that the presence of central lenders in the syndicate should play a weaker role. On the contrary, longer maturities or concentrated syndicates being

\footnotetext{
${ }^{12}$ In these cases, league table lenders' presence in the syndicate appears to be more important for loan pricing than banks' distance to the centre of the network or the local involvement in the network. We remind that closeness and degree measures are statistically correlated with league table variables.
} 
associated with riskier deals with greater moral hazard problems, we expect syndicate centrality to play a more important role.

Results are displayed in Table $6^{13}$. The first four columns correspond to sub-samples where information problems are expected to be severe. Large and complex loans imply more agency costs and coordination problems, while longer maturities are usually associated with greater risk. Larger syndicates are usually funding larger, more complex and riskier loans and coordination problems are more likely in such syndicates, while greater syndicate concentration is related to more severe moral hazard problems. The last three columns correspond to deals which are expected to have less information problems because of the exclusive presence of local lenders and of league table banks.

Overall, we remark that the main results remain robust in the sense that most centrality measures remain significant and negative, except for two specifications with closeness centrality and one specification with degree centrality. Regarding more informationally problematic deals (large loans, long maturities, large and concentrated syndicates), we observe that for each of the three syndicate centrality measures, coefficients are larger than to the main specifications in Tables 3,4 , and 5. The exceptions concern the Large syndicates specification for which coefficients are lower or not significant. We can interpret this result by the fact that larger syndicates could also signal better quality deals with less informational frictions and agency problems which allow the organization of a syndicate with more members (Lee and Mullineaux 2004; Sufi 2007). In such a case, the importance of experienced, reputable and central lenders appears to be less important.

When turning to deals where informational frictions should be less problematic (many local lenders and numerous league table banks), we remark that evidence is more mixed. Coefficients for syndicate centrality measures are lower or even not significant for deals funded exclusively by French banks. Such deals leave less room for informational frictions and agency problems because of the presence of better informed local lenders thus the importance of central lenders is less of an issue. However, evidence is less clear-cut for deals funded by numerous league table lenders. Overall, it seems that syndicate centrality matters, even very much, for such deals. We can explain this result by stating that the probability of having central syndicate members increases with the presence of league table banks. Indeed, centrality measures and league table variables are significantly correlated and they are larger for the Many league table sub-sample than the average values for the whole sample.

\footnotetext{
${ }^{13}$ We do not display coefficients for main loan characteristics to save space. These coefficients remain robust and exhibit similar signs and significance levels as in tables 3,4 , and 5 .
} 


\section{Conclusion}

Using a large sample of almost 1000 syndicated loans for French companies over a long period (19922006), we first analyze the small world properties of the French syndicated lending market. A small world is a locally dense social network where social distances between actors are short. Such network improves market's efficiency as it allows larger information and resources flows as well as actors' social capital, experience and reputation. We find that the dynamics of the French syndicated lending market tends to support that the networks of lenders become small worlds over time in the sense of Watts (2003). Hence, we provide additional evidence on the small world characteristics of syndicated lending markets, following the work of Baum, Shipilov, and Rowley (2003) and Baum, Rowley, and Shipilov (2004) who found that the Canadian syndicated lending market also exhibit small world features.

We then investigate the impact of the lenders' individual network characteristics on borrower wealth by evaluating the sensitivity of loan pricing to lenders' experience and reputation which we proxy using network centrality measures of banks. We rely on three most widely used centrality measures: betweenness, closeness and degree, each measuring a different aspect of the lender's network position. Regressions of the loan spread on these experience and reputation proxies show that borrowers can gain from reduced loan pricing when they are funded by syndicates composed of lenders that are more central on the syndicated lending market. In particular, lenders' betweenness centrality appears to be a crucial characteristic for borrowing costs reduction. Hence, the presence of such experienced and reputable lenders having access to greater amounts and flows of information and resources serves as a device mitigating informational frictions and agency costs related to loan syndication. These results provide additional evidence on the role of experience and reputation on the syndicated lending market, following notably Panyagometh and Roberts (2010) and Ross (2010).

Overall, the organization of the syndicated lending market matters for successful bank loan syndication. In particular, its capacity to enhance lenders' interaction, reciprocity, trust, experience, and reputation has important implications for mitigating information costs. This in turn contributes to the development of the market and the reduction of the borrowing costs. 


\section{References}

Allen, F., and A. Babus. 2008. Networks in Finance. Working Paper.

Arrow, K. J. 1974. The Limits of Organization. W. W. Norton \& Company.

Baum, J. A. C., A. V. Shipilov, and T. J. Rowley. 2003. Where Do Small Worlds Come From? Industrial Corporate Change 12: 697-725.

Baum, J. A. C., T. J. Rowley, and A. V. Shipilov. 2004. The Small World of Canadian Capital Markets: Statistical Mechanics of Investment Bank Syndicate Networks, 1952-1989. Canadian Journal of Administrative Sciences / Revue Canadienne des Sciences de l'Administration 21: 307-325.

Bolton, P., and D. S. Scharfstein. 1996. Optimal Debt Structure and the Number of Creditors. Journal of Political Economy 104: 1-25.

Cai, J. 2010. Competition or Collaboration? The Reciprocity Effect in Loan Syndication. Working Paper.

Cai, J., A. Saunders, and S. Steffen. 2010. Diversification or Specialization? An Analysis of Distance and Collaboration in Loan Syndication Networks. Working Paper.

Carpenter, J., S. Bowles, H. Gintis, and S.-H. Hwang. 2009. Strong Reciprocity and Team Production: Theory and Evidence. Journal of Economic Behavior \& Organization 71, 2: 221-232.

Champagne, C., and L. Kryzanowski. 2007. Are Current Syndicated Loan Alliances Related to Past Alliances? Journal of Banking and Finance 31: 3145-3161.

Cohen, L., A. Frazzini, and C. Malloy. 2008. The Small World of Investing: Board Connections and Mutual Fund Returns. Journal of Political Economy 116: 951-979.

Coleman, J. S. 1988. Social Capital in the Creation of Human Capital. American Journal of Sociology 94: S95.

Davis, G. F., M. Yoo, and W. E. Baker. 2003. The Small World of the American Corporate Elite, 1982-2001. Strategic Organization 1: 301-326.

Dennis, S. A., and D. J. Mullineaux. 2000. Syndicated Loans. Journal of Financial Intermediation 9: 404-426.

Di Cagno, D., and E. Sciubba. 2010. Trust, Trustworthiness and Social Networks: Playing a Trust Game when Networks are Formed in the Lab. Journal of Economic Behavior \& Organization (forthcoming).

Esty, B. C. 2001. Structuring Loan Syndicates: A Case Study of the Hong Kong Disneyland Project Loan. Journal of Applied Corporate Finance 14: 80-95.

Esty, B. C., and W. L. Megginson. 2003. Creditor Rights, Enforcement, and Debt Ownership Structure: Evidence from the Global Syndicated Loan Market. Journal of Financial and Quantitative Analysis 38: 37-59.

Focarelli, D., A. F. Pozzolo, and L. Casolaro. 2008. The Pricing Effect of Certification on Syndicated Loans. Journal of Monetary Economics 55: 335-349.

François, P., and F. Missonnier-Piera. 2007. The Agency Structure of Loan Syndicates. Financial Review 42: 227245.

Gatti, S., S. Kleimeier, W. L. Megginson, and A. Steffanoni. 2008. Arranger Certification in Project Finance. Working Paper.

Godlewski, C. J. 2009. L'organisation des syndicats bancaires en France : Taille, concentration et réputation. Finance Contrôle Stratégie 12: 37-63.

-- - 2010. Banking Environment and Loan Syndicate Structure: A Cross-Country Analysis. Applied Financial Economics 20, 8: 637-647.

Gopalan, R., V. Nanda, and V. Yerramilli. 2007. Lead Arranger Reputation and the Loan Syndication Market. Working Paper.

Gulati, R. 1998. Alliances and Networks. Strategic Management Journal 19: 293-317.

Hochberg, Y. V., A. Ljungqvist, and Y. Lu. 2007. Whom You Know Matters: Venture Capital Networks and Investment Performance. Journal of Finance 62: 251-301.

Ivashina, V. 2009. Asymmetric Information Effects on Loan Spreads. Journal of Financial Economics 92: 300-319.

Jones, J. D., W. W. Lang, and P. J. Nigro. 2005. Agent Behavior in Bank Loan Syndications. Journal of Financial Research 28: 385-402.

Kogut, B., P. Urso, and G. Walker. 2007. Emergent Properties of a New Financial Market: American Venture Capital Syndication, 1960-2005. Management Science 53: 1181-1198.

Lee, S. W., and D. J. Mullineaux. 2004. Monitoring, Financial Distress, and the Structure of Commercial Lending Syndicates. Financial Management 33: 107-130.

McCahery, J., and A. Schwienbacher. 2010. Bank Reputation in the Private Debt Market. Journal of Corporate Finance (forthcoming).

Meuleman, M., M. Wright, S. Manigart, and A. Lockett. 2009. Private Equity Syndication: Agency Costs, Reputation and Collaboration. Journal of Business Finance \& Accounting 36: 616-644.

Morrison, A. D., and W. J. Wilhelm. 2007. Investment Banking: Institutions, Politics, and Law. Oxford University 
Press.

Newman, M. E. J., S. H. Strogatz, and D. J. Watts. 2001. Random Graphs With Arbitrary Degree Distributions and Their Applications. Physical Review E 64: 026118.

Panyagometh, K., and G. S. Roberts. 2010. Do Lead Banks Exploit Syndicate Participants? Evidence from Ex Post Risk. Financial Management 39: 273-299.

Pennachi, G. G. 1998. Loan Sales and the Cost of Bank Capital. Journal of Finance 43: 375-396.

Rhodes, T. 2004. Syndicated Lending Practice and Document. Euromoney Books.

Ross, D. 2010. The "Dominant Bank Effect": How High Lender Reputation Affects The Information Content and Terms of Bank Loans'. Review of Financial Studies (forthcoming).

Schnabel, I., and H. S. Shin. 2004. Liquidity and Contagion: The Crisis of 1763. Journal of the European Economic Association 2: 929-968.

Song, F. 2009. Intergroup Trust and Reciprocity in Strategic Interactions: Effects of Group Decision-Making Mechanisms. Organizational Behavior and Human Decision Processes 108: 164-173.

Sufi, A. 2007. Information Asymmetry and Financing Arrangements: Evidence from Syndicated Loans. Journal of Finance 62: 629-668.

Thomson Financial. 2009. Syndicated Loans Review. Thomson.

Uzzi, B., L. A. N. Amaral, and F. Reed-Tsochas. 2007. Small-World Networks and Management Science Research: A Review. European Management Review 4: 77-91.

Uzzi, B., and J. Spiro. 2005. Collaboration and Creativity: The Small World Problem. American Journal of Sociology 111: 447-504.

Watts, D. J., and S. H. Strogatz. 1998. Collective Dynamics of 'Small-World' Networks. Nature 393: 440-442.

Watts, D. J. 2003. Small Worlds: The Dynamics of Networks between Order and Randomness. Princeton University Press. 
(a)

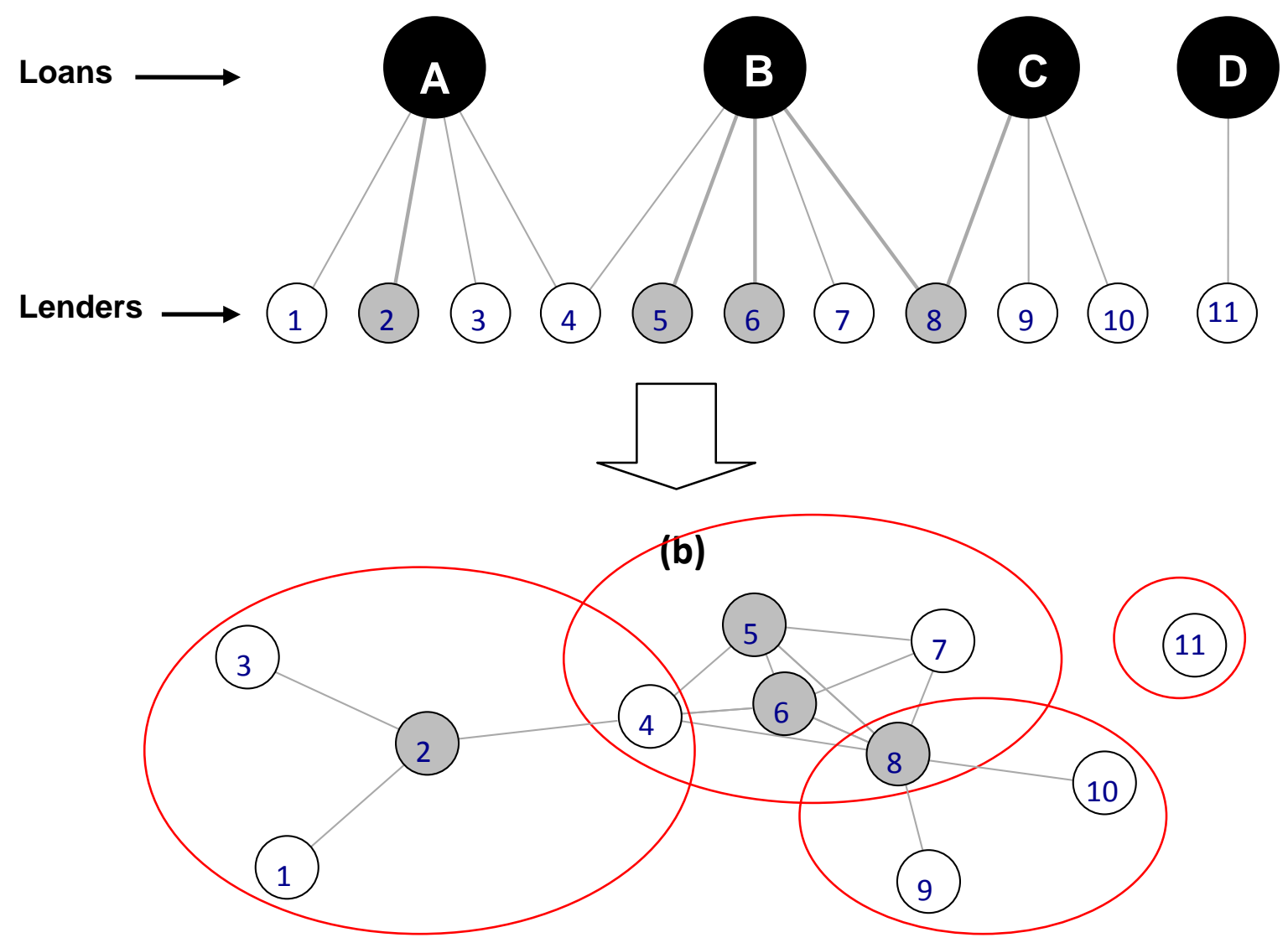

Figure 1 Constructing a network of lenders

Deals $(A, B, C, D)$ are shown in black, lead arrangers $(2,5,6$, and 8$)$ in gray, other participants in white.

(a) Bipartite network of syndicated deals (A, B, C) and lenders ( 1 to 10). Lender 2 is the leader in deal A, lenders 5, 6, and 8 are leaders in deal $B$, and deal $C$ is led by bank 8 .

(b) One-mode projection of the bipartite network onto the set of lenders. The circles indicate corresponding deals. 


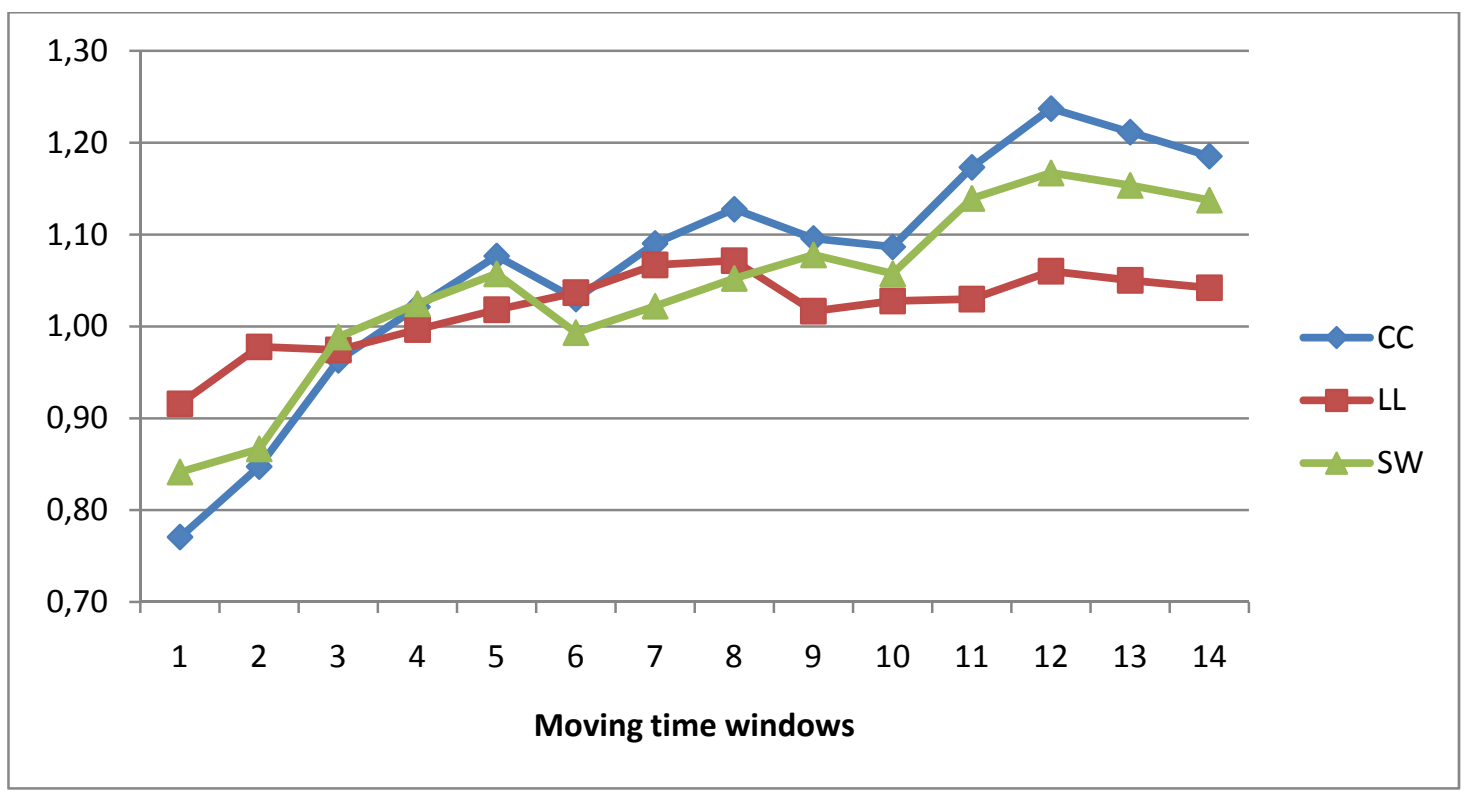

(A) Dynamics using simulated random network method

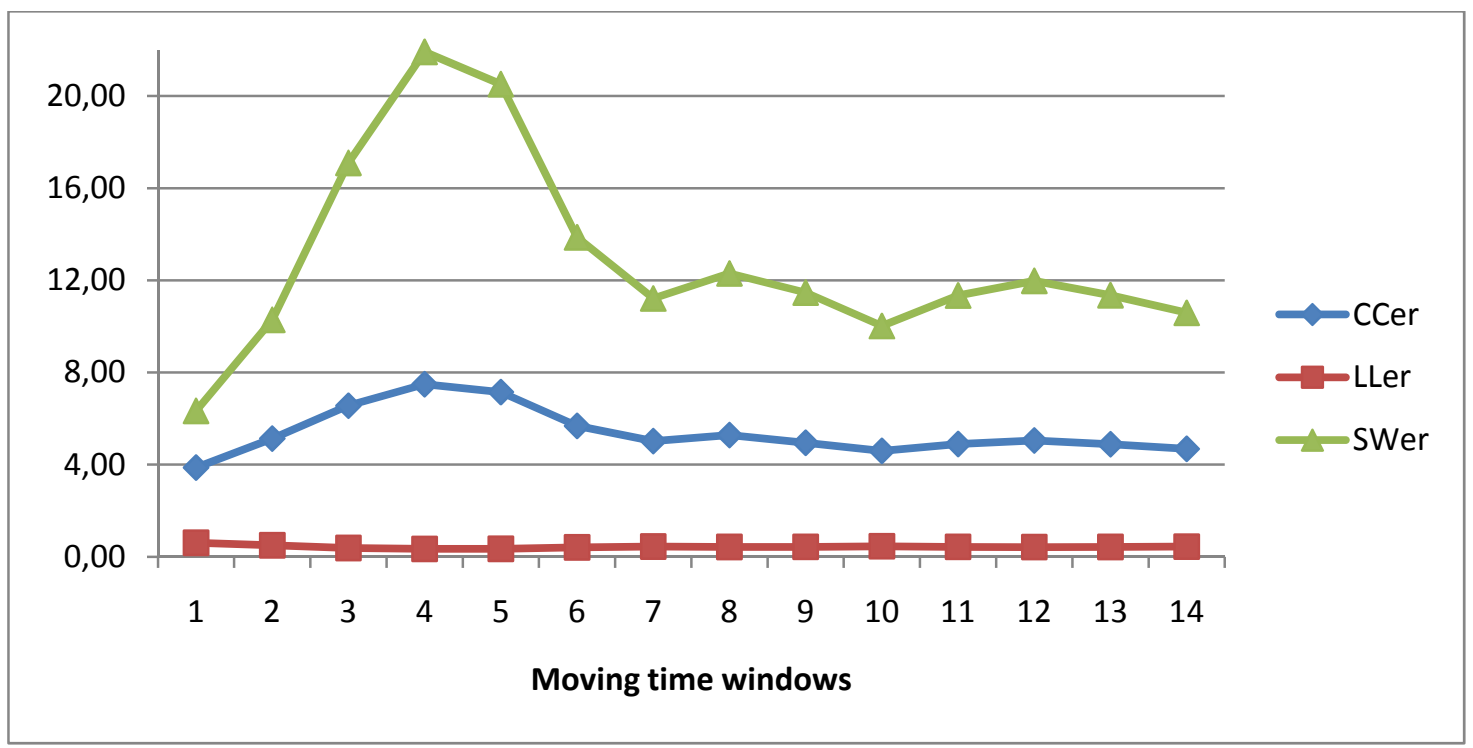

(B) Dynamics using Erdos-Renyi random network method

Figure 2 Dynamics of the average distance $(L L)$, clustering $(C C)$ and small-world ratio (SW)

CC and CCer: ratios of $\mathrm{Ca} / \mathrm{Cr}$ and Ca / Cer respectively. LL and LLer: ratios of La / Lr and La / Ler. SW and SWer: small world ratios defined as CC / LL and CCer / LLer respectively. Ca: clustering of the actual network. La: average distance of the actual network. $\mathrm{Cr}$ and Cer: clustering of the simulated and Erdos-Renyi random networks respectively. $\mathrm{Lr}$ and Ler: average distance of the simulated and Erdos-Renyi random networks respectively. 

characteristics

This table provides the description and main statistics for syndicate, loan, and lender's individual network characteristics in the sample.

\begin{tabular}{llrr}
\hline Variables & Description & Mean & Std. dev. \\
\hline Spread & Loan spread in bps over benchmark rate & 120.2581 & 119.4219 \\
Loan amount & Loan amount in millions \$ & 1890.0000 & 3160.0000 \\
Maturity & Loan maturity in months & 70.6261 & 36.6228 \\
Guarantors & $=1$ if guarantors are present & 0.0645 & 0.2456 \\
Covenants & $=1$ if financial covenants are present & 0.1044 & 0.3058 \\
Number of arrangers & Number of arrangers in the syndicate & 5.3465 & 5.4026 \\
Number of lenders & Number of lenders in the syndicate & 14.3789 & 10.5990 \\
Local lenders & \% of French lenders in the syndicate & 0.4097 & 0.2909 \\
Syndicate concentration & Average \% of the loan held by arrangers in the syndicate & 0.1178 & 0.1422 \\
League table & \% of league tables lenders in the syndicate & 0.3400 & 0.2129 \\
League table (local) & \% of league table French lenders in the syndicate & 0.1487 & 0.1734 \\
Corporate purpose & $=1$ if loan purpose is corporate purpose & 0.1806 & 0.3847 \\
Debt repay purpose & $=1$ if loan purpose is debt repayment & 0.3522 & 0.4777 \\
LBo purpose & $=1$ if loan purpose is LBO & 0.1659 & 0.3720 \\
Term loan & $=1$ if loan is a term loan & 0.3161 & 0.4649 \\
Revolving loan & $=1$ if loan is a revolving loan & 0.4048 & 0.4909 \\
Libor & $=1$ if loan benchmark rate is Libor & 0.2839 & 0.4509 \\
\hline Betweenness & Average lenders' betweenness by syndicate & 0.0155 & 0.0080 \\
Closeness & Average lender's closeness by syndicate & 0.5218 & 0.0316 \\
Degree & Average lender's degree by syndicate & 219.7680 & 86.7679 \\
\hline & &
\end{tabular}


This table displays network characteristics for the French syndicated lending market over the period 1992-2006. The first column displays the overlapping moving time windows while the second and third columns indicate the first and last year of the period under investigation. Each of the 14 overlapping periods contains 5 years of observations (except for the periods 1, 13, and 14). Columns 4 to 7 display the number of syndicated deals, the number of different lenders involved, the number of links between lenders, and the number of isolated lenders respectively. Columns 8 to 10 display the largest component (LC), the clustering of the actual network (Ca), and the average distance of the actual network (La). Columns 11 to 13 display the clustering of the simulated random network (Cr), the average distance of the simulated random network (Lr), and the small world ratio (SW) defined as CC / LL. Columns 14 to 16 display the clustering of the Erdos-Renyi random network (Cer), the average distance of the Erdos-Renyi random network (Ler), and the small world ratio (SWer) defined as CCer / LLer.

\begin{tabular}{rrrrrrrrrrrrrrrrrrrrrrrrrrrrrr}
\hline $\begin{array}{r}\text { Moving } \\
\text { time } \\
\text { window }\end{array}$ & start & end & \#deals & \#lenders & \#links & \#isolates & LC & Ca & La & Cr & Lr & SW & Cer & Ler & SWer \\
\hline 1 & 1992 & 1995 & 82 & 166 & 679 & 7 & 159 & 0,2031 & 2,363 & 0,2635 & 2,5804 & 0,8415 & 0,0525 & 2,627 & 6,3334 \\
2 & 1992 & 1996 & 137 & 209 & 907 & 12 & 197 & 0,2278 & 2,5595 & 0,2688 & 2,6178 & 0,8666 & 0,0444 & 2,6747 & 10,2846 \\
3 & 1992 & 1997 & 167 & 221 & 1104 & 15 & 206 & 0,312 & 2,5138 & 0,3239 & 2,58 & 0,9885 & 0,0476 & 2,5713 & 17,0909 \\
4 & 1993 & 1998 & 214 & 258 & 1404 & 19 & 234 & 0,3319 & 2,5614 & 0,325 & 2,5699 & 1,0247 & 0,0443 & 2,566 & 21,9144 \\
5 & 1994 & 1999 & 265 & 283 & 2082 & 13 & 265 & 0,3947 & 2,493 & 0,3666 & 2,4483 & 1,0573 & 0,0552 & 2,37 & 20,5085 \\
6 & 1995 & 2000 & 375 & 363 & 4467 & 10 & 345 & 0,4096 & 2,327 & 0,3978 & 2,2446 & 0,9933 & 0,0721 & 2,1078 & 13,8693 \\
7 & 1996 & 2001 & 415 & 356 & 6143 & 15 & 338 & 0,4879 & 2,2473 & 0,4474 & 2,1064 & 1,022 & 0,0972 & 1,934 & 11,2116 \\
8 & 1997 & 2002 & 427 & 352 & 5851 & 16 & 331 & 0,5002 & 2,2685 & 0,4436 & 2,1169 & 1,0523 & 0,0947 & 1,9438 & 12,2984 \\
9 & 1998 & 2003 & 480 & 367 & 6319 & 16 & 351 & 0,4656 & 2,1345 & 0,4249 & 2,0995 & 1,0779 & 0,0941 & 1,9412 & 11,4697 \\
10 & 1999 & 2004 & 510 & 391 & 7745 & 16 & 375 & 0,467 & 2,1086 & 0,4298 & 2,0518 & 1,0573 & 0,1016 & 1,9143 & 10,0196 \\
11 & 2000 & 2005 & 490 & 387 & 7683 & 18 & 369 & 0,5038 & 2,1127 & 0,4294 & 2,0517 & 1,1394 & 0,1029 & 1,912 & 11,3461 \\
12 & 2001 & 2006 & 563 & 377 & 7465 & 16 & 361 & 0,5322 & 2,1285 & 0,4302 & 2,0079 & 1,1671 & 0,1054 & 1,9083 & 11,9783 \\
13 & 2002 & 2006 & 577 & 392 & 8151 & 15 & 375 & 0,5186 & 2,0999 & 0,428 & 1,9994 & 1,1535 & 0,1062 & 1,9041 & 11,3558 \\
14 & 2003 & 2006 & 494 & 347 & 6634 & 15 & 329 & 0,5174 & 2,0703 & 0,4365 & 1,9867 & 1,1374 & 0,1105 & 1,9023 & 10,59 \\
\hline
\end{tabular}


This table provides the results of OLS regressions with standard errors clustered the loan level. The dependent variable is the logarithm of the loan spread (bps) over the benchmark rate. The level of observation is lender-tranche. All regressions include loan purpose dummies (Corporate, Debt repay, and LBO), type of loan dummies (Term and Revolving), Libor dummy, and dummies for industrial sectors and years. Lenders fixed effects takes main lender's countries into account through dummies for lenders from France, Germany, Japan, Netherlands, UK, and US. ***,**, * correspond to coefficients statistically different from 0 at the $1 \%, 5 \%$, and $10 \%$ confidence level. All variables are described in table 1.

\begin{tabular}{|c|c|c|c|c|c|c|}
\hline Variables & Model 1.1 & Model 1.2 & Model 1.3 & Model 1.4 & Model 1.5 & Model 1.6 \\
\hline Betweenness & $\begin{array}{c}-24.220 * * * \\
(5.795)\end{array}$ & $\begin{array}{c}-23.438 * * * \\
(5.462)\end{array}$ & $\begin{array}{c}-23.750 * * * \\
(5.738)\end{array}$ & $\begin{array}{c}-18.381 * * \\
(8.065)\end{array}$ & $\begin{array}{c}-1.866 * * * \\
(0.651)\end{array}$ & $\begin{array}{c}-2.405^{* * *} \\
(0.707)\end{array}$ \\
\hline Loan amount & $\begin{array}{c}-0.220 * * * \\
(0.037)\end{array}$ & $\begin{array}{c}-0.242^{* * *} \\
(0.038)\end{array}$ & $\begin{array}{c}-0.226 * * * \\
(0.039)\end{array}$ & $\begin{array}{c}-0.205^{* * *} \\
(0.054)\end{array}$ & $\begin{array}{c}-0.221 * * * \\
(0.037)\end{array}$ & $\begin{array}{c}-0.243 * * * \\
(0.038)\end{array}$ \\
\hline Maturity & $\begin{array}{c}0.003 * * * \\
(0.001)\end{array}$ & $\begin{array}{c}0.003 * * * \\
(0.000)\end{array}$ & $\begin{array}{c}0.003^{* * *} \\
(0.001)\end{array}$ & $\begin{array}{c}0.000 \\
(0.001)\end{array}$ & $\begin{array}{c}0.003 * * * \\
(0.001)\end{array}$ & $\begin{array}{c}0.003^{* * *} \\
(0.001)\end{array}$ \\
\hline Guarantors & $\begin{array}{l}-0.237 \\
(0.168)\end{array}$ & $\begin{array}{l}-0.233 \\
(0.158)\end{array}$ & $\begin{array}{l}-0.242 \\
(0.169)\end{array}$ & $\begin{array}{c}-0.507^{*} \\
(0.269)\end{array}$ & $\begin{array}{l}-0.185 \\
(0.177)\end{array}$ & $\begin{array}{l}-0.193 \\
(0.168)\end{array}$ \\
\hline Covenants & $\begin{array}{l}-0.139 \\
(0.153)\end{array}$ & $\begin{array}{l}-0.192 \\
(0.144)\end{array}$ & $\begin{array}{l}-0.140 \\
(0.154)\end{array}$ & $\begin{array}{c}-0.435^{* *} \\
(0.193)\end{array}$ & $\begin{array}{l}-0.107 \\
(0.153)\end{array}$ & $\begin{array}{l}-0.109 \\
(0.158)\end{array}$ \\
\hline $\begin{array}{l}\text { Number of } \\
\text { lenders }\end{array}$ & & $\begin{array}{l}0.010 * \\
(0.005)\end{array}$ & & & & \\
\hline Local lenders & & & $\begin{array}{l}-0.114 \\
(0.121)\end{array}$ & & & \\
\hline $\begin{array}{l}\text { Syndicate } \\
\text { concentration }\end{array}$ & & & & $\begin{array}{c}0.274 \\
(0.408)\end{array}$ & & \\
\hline League table & & & & & $\begin{array}{c}-0.600 * * * \\
(0.207)\end{array}$ & \\
\hline $\begin{array}{l}\text { League table } \\
\text { (local) }\end{array}$ & & & & & & $\begin{array}{c}-0.611^{* * *} \\
(0.186)\end{array}$ \\
\hline Intercept & $\begin{array}{c}8.775^{* * *} \\
(0.736)\end{array}$ & $\begin{array}{c}9.153^{* * *} \\
(0.774)\end{array}$ & $\begin{array}{c}8.949 * * * \\
(0.771)\end{array}$ & $\begin{array}{c}9.083 * * * \\
(1.051)\end{array}$ & $\begin{array}{c}8.759 * * * \\
(0.724)\end{array}$ & $\begin{array}{c}9.158 * * * \\
(0.772)\end{array}$ \\
\hline $\begin{array}{l}\text { Lender fixed } \\
\text { effects }\end{array}$ & Yes & No & No & No & No & No \\
\hline N. obs. & 12376 & 12367 & 12376 & 6191 & 12376 & 12376 \\
\hline $\mathbf{R}^{2}$ & 0.529 & 0.533 & 0.529 & 0.503 & 0.520 & 0.517 \\
\hline $\mathbf{F}$ & 29.142 & 29.669 & 30.613 & 14.829 & 32.693 & 33.652 \\
\hline
\end{tabular}


This table provides the results of OLS regressions with standard errors clustered at the loan level. The dependent variable is the logarithm of the loan spread (bps) over the benchmark rate. The level of observation is lender-tranche. All regressions include loan purpose dummies (Corporate, Debt repay, and LBO), type of loan dummies (Term and Revolving), Libor dummy, and dummies for industrial sectors and years. Lenders fixed effects takes main lender's countries into account through dummies for lenders from France, Germany, Japan, Netherlands, UK, and US. ${ }^{* *},{ }^{* *}, *$ correspond to coefficients statistically different from 0 at the $1 \%, 5 \%$, and $10 \%$ confidence level. All variables are described in table 1.

\begin{tabular}{|c|c|c|c|c|c|c|}
\hline Variables & Model 2.1 & Model 2.2 & Model 2.3 & Model 2.4 & Model 2.5 & Model 2.6 \\
\hline \multirow[t]{2}{*}{ Closeness } & $-3.1359 * *$ & $-3.1626 * *$ & $-3.0618 * *$ & -2.8145 & -1.1202 & -2.2503 \\
\hline & (1.4858) & $(1.4301)$ & $(1.4684)$ & (1.9891) & (1.8355) & (1.5748) \\
\hline \multirow[t]{2}{*}{ Loan amount } & $-0.2222 * * *$ & $-0.2461^{* * *}$ & $-0.2293 * * *$ & $-0.2029 * * *$ & $-0.2227 * * *$ & $-0.2407 * * *$ \\
\hline & (0.0379) & (0.0392) & $(0.0397)$ & $(0.0556)$ & $(0.0376)$ & $(0.0397)$ \\
\hline \multirow[t]{2}{*}{ Maturity } & $0.0033^{* * *}$ & $0.0032^{* * *}$ & $0.0033^{* * *}$ & 0.0006 & $0.0032 * * *$ & $0.0033^{* * *}$ \\
\hline & $(0.0011)$ & $(0.0009)$ & $(0.0010)$ & $(0.0013)$ & $(0.0011)$ & $(0.0010)$ \\
\hline \multirow[t]{2}{*}{ Guarantors } & -0.2222 & -0.2177 & -0.2264 & $-0.5111^{*}$ & -0.1993 & -0.2120 \\
\hline & (0.1696) & $(0.1578)$ & $(0.1704)$ & $(0.2680)$ & $(0.1771)$ & $(0.1672)$ \\
\hline \multirow[t]{2}{*}{ Covenants } & -0.1276 & -0.1867 & -0.1292 & $-0.4166 * *$ & -0.1106 & -0.1181 \\
\hline & (0.1582) & $(0.1480)$ & (0.1598) & $(0.1963)$ & $(0.1541)$ & $(0.1582)$ \\
\hline \multirow{2}{*}{$\begin{array}{l}\text { Number of } \\
\text { lenders }\end{array}$} & & $0.0119 *$ & & & & \\
\hline & & $(0.0062)$ & & & & \\
\hline \multirow[t]{2}{*}{ Local lenders } & & & -0.1450 & & & \\
\hline & & & $(0.1236)$ & & & \\
\hline \multirow{2}{*}{$\begin{array}{l}\text { Syndicate } \\
\text { concentration }\end{array}$} & & & & 0.2648 & & \\
\hline & & & & $(0.4092)$ & & \\
\hline \multirow[t]{2}{*}{ League table } & & & & & $-0.5693 * *$ & \\
\hline & & & & & $(0.2541)$ & \\
\hline \multirow{3}{*}{$\begin{array}{l}\text { Local league } \\
\text { table }\end{array}$} & & & & & & $-0.5234^{* *}$ \\
\hline & & & & & & $(0.2056)$ \\
\hline & $(0.1210)$ & $(0.1135)$ & $(0.1217)$ & $(0.1980)$ & $(0.1205)$ & $(0.1200)$ \\
\hline \multirow[t]{2}{*}{ Intercept } & $10.0758^{* * *}$ & $10.4952 * * *$ & $10.2462^{* * *}$ & $10.1813^{* * *}$ & $9.2246 * * *$ & $10.1177^{* * *}$ \\
\hline & $(0.9389)$ & $(0.9965)$ & $(0.9653)$ & (1.3249) & $(1.0542)$ & (0.9394) \\
\hline $\begin{array}{l}\text { Lender fixed } \\
\text { effects }\end{array}$ & Yes & No & No & No & No & No \\
\hline N. obs. & 12376 & 12367 & 12376 & 6191 & 12376 & 12376 \\
\hline $\mathbf{R}^{2}$ & 0.5156 & 0.5209 & 0.5155 & 0.4969 & 0.5209 & 0.5185 \\
\hline $\mathbf{F}$ & 28.0483 & 29.6803 & 30.5641 & 14.9921 & 31.0070 & 31.5757 \\
\hline
\end{tabular}


This table provides the results of OLS regressions with standard errors clustered at the loan level. The level of observation is lender-tranche. The dependent variable is the logarithm of the loan spread (bps) over the benchmark rate. All regressions include loan purpose dummies (Corporate, Debt repay, and LBO), type of loan dummies (Term and Revolving), Libor dummy, and dummies for industrial sectors and years. Lenders fixed effects takes main lender's countries into account through dummies for lenders from France, Germany, Japan, Netherlands, UK, and US. ***, **, * correspond to coefficients statistically different from 0 at the $1 \%, 5 \%$, and $10 \%$ confidence level. All variables are described in table 1.

\begin{tabular}{|c|c|c|c|c|c|c|}
\hline Variables & Model 3.1 & Model 3.2 & Model 3.3 & Model 3.4 & Model 3.5 & Model 3.6 \\
\hline \multirow[t]{2}{*}{ Degree } & $-0.0014 * *$ & $-0.0014 * *$ & $-0.0014 * *$ & $-0.0012^{*}$ & -0.0007 & $-0.0011^{*}$ \\
\hline & $(0.0006)$ & $(0.0006)$ & $(0.0006)$ & $(0.0007)$ & $(0.0008)$ & $(0.0006)$ \\
\hline \multirow[t]{2}{*}{ Loan amount } & $-0.2186 * * *$ & $-0.2421 * * *$ & $-0.2258 * * *$ & $-0.2006 * * *$ & $-0.2208 * * *$ & $-0.2361 * * *$ \\
\hline & $(0.0382)$ & $(0.0395)$ & $(0.0399)$ & $(0.0555)$ & $(0.0379)$ & $(0.0403)$ \\
\hline \multirow[t]{2}{*}{ Maturity } & $0.0031^{* * *}$ & $0.0031 * * *$ & $0.0032 * * *$ & 0.0005 & $0.0032 * * *$ & $0.0033^{* * *}$ \\
\hline & $(0.0010)$ & $(0.0009)$ & $(0.0010)$ & $(0.0013)$ & $(0.0010)$ & $(0.0010)$ \\
\hline \multirow[t]{2}{*}{ Guarantors } & -0.2379 & -0.2336 & -0.2426 & $-0.5072^{*}$ & -0.2100 & -0.2257 \\
\hline & (0.1698) & (0.1579) & $(0.1704)$ & $(0.2676)$ & $(0.1761)$ & $(0.1679)$ \\
\hline \multirow[t]{2}{*}{ Covenants } & -0.1404 & -0.1983 & -0.1420 & $-0.4340 * *$ & -0.1185 & -0.1287 \\
\hline & $(0.1573)$ & $(0.1472)$ & $(0.1589)$ & $(0.1958)$ & $(0.1541)$ & $(0.1578)$ \\
\hline \multirow[t]{2}{*}{ Number of lenders } & & $0.0117^{*}$ & & & & \\
\hline & & $(0.0061)$ & & & & \\
\hline \multirow[t]{2}{*}{ Local lenders } & & & -0.1459 & & & \\
\hline & & & $(0.1234)$ & & & \\
\hline \multirow[t]{2}{*}{ Syndicate concentration } & & & & 0.2548 & & \\
\hline & & & & $(0.4088)$ & & \\
\hline \multirow[t]{2}{*}{ League table } & & & & & $-0.5178 *$ & \\
\hline & & & & & $(0.2682)$ & \\
\hline \multirow[t]{2}{*}{ Local league table } & & & & & & $-0.4749 * *$ \\
\hline & & & & & & $(0.2137)$ \\
\hline \multirow[t]{2}{*}{ Intercept } & $8.6073 * * *$ & $9.0085^{* * *}$ & $8.8169 * * *$ & $8.8981 * * *$ & $8.6964 * * *$ & $9.0248^{* * *}$ \\
\hline & $(0.7358)$ & $(0.7751)$ & $(0.7720)$ & $(1.0671)$ & $(0.7352)$ & $(0.7903)$ \\
\hline Lender fixed effects & Yes & No & No & No & No & No \\
\hline N. obs. & 12376 & 12367 & 12376 & 6191 & 12376 & 12376 \\
\hline $\mathbf{R}^{2}$ & 0.5176 & 0.5227 & 0.5175 & 0.4988 & 0.5215 & 0.5197 \\
\hline $\mathbf{F}$ & 27.1606 & 29.1862 & 29.8898 & 14.7081 & 30.8546 & 30.8622 \\
\hline
\end{tabular}


This table provides the results of OLS regressions with standard errors clustered at the loan level. The dependent variable is the logarithm of the loan spread (bps) over the benchmark rate. The level of observation is lender-tranche. All regressions include loan main characteristics (Loan amount, Maturity, Guarantors, Covenants), loan purpose dummies (Corporate, Debt repay, and LBO), type of loan dummies (Term and Revolving), Libor dummy, and dummies for industrial sectors and years. The first regression is for large loans (loan amount greater than sample median: 662.7 millions \$). The second regression is for long maturities (maturities greater than sample median: 61 months). The third regression is for concentrated syndicates (\% of loan held by arrangers greater than sample median: 0.065). The fourth regression is for large syndicates (number of lenders greater than sample median: 13). The fifht regression is for loans funded by French lenders only. The sixth regression is for syndicates with many league table lenders (\% of league table lenders greater than sample median: 0.29). The seventh regression is for syndication with many local league table lenders (\% of French league table lenders greater than sample median: 0.09). ***, **, * correspond to coefficients statistically different from 0 at the $1 \%, 5 \%$, and $10 \%$ confidence level. All variables are described in table 1.

\begin{tabular}{lccccccc}
\hline Variables & $\begin{array}{c}\text { Large } \\
\text { loans }\end{array}$ & $\begin{array}{c}\text { Long } \\
\text { maturities }\end{array}$ & $\begin{array}{c}\text { Large } \\
\text { syndicates }\end{array}$ & $\begin{array}{c}\text { Concentrated } \\
\text { syndicates }\end{array}$ & French lenders only & Many league table & $\begin{array}{c}\text { Many league } \\
\text { table (local) }\end{array}$ \\
\hline Betweenness & $-28.1563^{* * *}$ & $-25.4679^{* * *}$ & $-20.3959^{* *}$ & $-28.1036^{* * *}$ & $-19.8812^{* * *}$ & $-1.3902^{* *}$ & $-2.8697^{* * *}$ \\
& $(10.3210)$ & $(6.7935)$ & $(9.8816)$ & $(8.3596)$ & $(5.3377)$ & $(0.5843)$ & $(0.7856)$ \\
\hline $\mathbf{N}$. obs. & 6303 & 6338 & 6592 & 2907 & 4982 & 6455 & 6306 \\
$\mathbf{R}^{\mathbf{2}}$ & 0.5573 & 0.7078 & 0.5717 & 0.5161 & 0.5159 & 0.6330 & 0.5851 \\
$\mathbf{F}$ & 24.0023 & 27.3561 & 27.5264 & 13.1325 & 24.3822 & 29.4552 & 33.4562 \\
\hline Closeness & $-5.7443^{* * *}$ & $-5.3414^{* * *}$ & -0.5550 & $-5.8459^{* * *}$ & -2.1173 & $-3.0566^{*}$ & $-3.1368^{*}$ \\
& $(2.1960)$ & $(1.5715)$ & $(2.6722)$ & $(2.0086)$ & $(1.4943)$ & $(1.7610)$ & $(1.8798)$ \\
\hline $\mathbf{N}$. obs. & 6303 & 6338 & 6592 & 2907 & 4982 & 6455 & 6306 \\
$\mathbf{R}^{\mathbf{2}}$ & 0.5502 & 0.7030 & 0.5640 & 0.5033 & 0.5040 & 0.6371 & 0.6024 \\
$\mathbf{F}$ & 22.8317 & 28.5250 & 25.3508 & 13.8550 & 23.8497 & 29.3336 & 31.1840 \\
\hline Degree & $-0.0020^{* *}$ & $-0.0023^{* * *}$ & -0.0001 & $-0.0024^{* * *}$ & $-0.0012^{* *}$ & $-0.0018^{* * *}$ & $-0.0015^{* *}$ \\
& $(0.0008)$ & $(0.0006)$ & $(0.0009)$ & $(0.0008)$ & $(0.0006)$ & $(0.0006)$ & $(0.0008)$ \\
\hline $\mathbf{N}$. obs. & 6303 & 6338 & 6592 & 2907 & 4982 & 6455 & 6306 \\
$\mathbf{R}^{2}$ & 0.5509 & 0.7048 & 0.5640 & 0.5083 & 0.5066 & 0.6408 & 0.6048 \\
$\mathbf{F}$ & 21.5975 & 27.8184 & 25.1641 & 14.9018 & 23.5543 & 30.4838 & 30.1415 \\
\hline
\end{tabular}




\section{Appendix}

Table A List of lenders' countries

\begin{tabular}{|c|c|c|}
\hline Lender country & Obs. & Percent \\
\hline Argentina & 8 & 0,05 \\
\hline Australia & 101 & 0,59 \\
\hline Austria & 74 & 0,43 \\
\hline Bahrain & 7 & 0,04 \\
\hline Belgium & 450 & 2,63 \\
\hline Brazil & 3 & 0,02 \\
\hline Canada & 304 & 1,78 \\
\hline Chile & 1 & 0,01 \\
\hline China & 37 & 0,22 \\
\hline Denmark & 39 & 0,23 \\
\hline Egypt & 7 & 0,04 \\
\hline Finland & 1 & 0,01 \\
\hline France & 6011 & 35,17 \\
\hline Germany & 2693 & 15,76 \\
\hline Hong Kong & 396 & 2,32 \\
\hline Iceland & 10 & 0,06 \\
\hline India & 1 & 0,01 \\
\hline Ireland & 200 & 1,17 \\
\hline Israel & 4 & 0,02 \\
\hline Italy & 886 & 5,18 \\
\hline Japan & 1221 & 7,14 \\
\hline Jordan & 10 & 0,06 \\
\hline Kuwait & 8 & 0,05 \\
\hline Luxembourg & 117 & 0,68 \\
\hline Morocco & 6 & 0,04 \\
\hline Netherlands & 1112 & 6,51 \\
\hline Norway & 15 & 0,09 \\
\hline Poland & 2 & 0,01 \\
\hline Portugal & 43 & 0,25 \\
\hline Romania & 6 & 0,04 \\
\hline Saudi Arabia & 5 & 0,03 \\
\hline Singapore & 13 & 0,08 \\
\hline South Africa & 1 & 0,01 \\
\hline Spain & 497 & 2,91 \\
\hline Sweden & 21 & 0,12 \\
\hline Switzerland & 220 & 1,29 \\
\hline Tunisia & 2 & 0,01 \\
\hline USA & 1372 & 8,03 \\
\hline United Arab Emirates & 7 & 0,04 \\
\hline United Kingdom & 1176 & 6,88 \\
\hline
\end{tabular}


Table B Correlation matrix

* indicates a coefficient statistically different from 0 at the $10 \%$ confidence level.

\begin{tabular}{|c|c|c|c|c|c|c|c|c|c|c|c|c|c|}
\hline Variables & Betweenness & Closeness & Degree & Spread & $\begin{array}{c}\text { Loan } \\
\text { amount }\end{array}$ & Maturity & Guarantors & Covenants & $\begin{array}{c}\text { Number of } \\
\text { lenders }\end{array}$ & $\begin{array}{l}\text { Local } \\
\text { lenders }\end{array}$ & $\begin{array}{c}\text { Syndicate } \\
\text { concentration }\end{array}$ & League table & $\begin{array}{l}\text { League table } \\
\text { (local) }\end{array}$ \\
\hline Betweenness & 1.0000 & & & & & & & & & & & & \\
\hline Closeness & $0.6462^{*}$ & 1.0000 & & & & & & & & & & & \\
\hline Degree & $0.6303^{*}$ & $0.8879 *$ & 1.0000 & & & & & & & & & & \\
\hline Spread & $-0.2417^{*}$ & $-0.1395^{*}$ & $-0.1338^{*}$ & 1.0000 & & & & & & & & & \\
\hline Loan amount & $0.1266^{*}$ & $0.2603^{*}$ & $0.3581^{*}$ & $-0.3148^{*}$ & 1.0000 & & & & & & & & \\
\hline Maturity & $-0.0852^{*}$ & $-0.0659 *$ & $-0.0697^{*}$ & $0.2993 *$ & $0.0200^{*}$ & 1.0000 & & & & & & & \\
\hline Guarantors & $-0.0992 *$ & $-0.0869 *$ & $-0.1308^{*}$ & $0.0538^{*}$ & $-0.0777^{*}$ & $0.0768^{*}$ & 1.0000 & & & & & & \\
\hline Covenants & -0.0124 & -0.0113 & $-0.0346 *$ & $-0.0561^{*}$ & $0.0713^{*}$ & $-0.0237 *$ & $-0.0772^{*}$ & 1.0000 & & & & & \\
\hline Number of lenders & $-0.0371^{*}$ & $0.1363^{*}$ & $0.1875^{*}$ & $-0.1806^{*}$ & $0.5194^{*}$ & $0.0601 *$ & $-0.0918^{*}$ & $0.2272^{*}$ & 1.0000 & & & & \\
\hline Local lenders & $0.0627^{*}$ & $0.0347^{*}$ & 0.0054 & $0.1546 *$ & $-0.3002^{*}$ & $0.0561^{*}$ & -0.0126 & $-0.0423^{*}$ & $-0.2869 *$ & 1.0000 & & & \\
\hline Syndicate concentration & $-0.0914^{*}$ & $-0.1098^{*}$ & $-0.1622^{*}$ & $0.1439^{*}$ & $-0.1270^{*}$ & $0.1830^{*}$ & $-0.0369 *$ & $0.1249^{*}$ & $-0.3009 *$ & $0.1988^{*}$ & 1.0000 & & \\
\hline League table & $0.5327^{*}$ & $0.4734^{*}$ & $0.5314^{*}$ & $-0.1069 *$ & $0.0297^{*}$ & $-0.0311^{*}$ & $-0.0239 *$ & $0.0348^{*}$ & $-0.0355^{*}$ & $0.0716^{*}$ & $-0.0240^{*}$ & 1.0000 & \\
\hline League table (local) & $0.3007 *$ & $0.2400 *$ & $0.2441 *$ & $0.1149 *$ & $-0.2171 *$ & $0.0309 *$ & -0.0107 & $-0.0194 *$ & $-0.2749 *$ & $0.4298^{*}$ & $0.2027 *$ & $0.5676^{*}$ & 1.0000 \\
\hline
\end{tabular}




\section{Documents de travail du BETA}

2010-01 The Aggregation of Individual Distributive Preferences through the Distributive Liberal Social Contract : Normative Analysis

Jean MERCIER-YTHIER, janvier 2010.

2010-02 Monnaie et Crise Bancaire dans une Petite Economie Ouverte Jin CHENG, janvier 2010.

2010-03 A Structural nonparametric reappraisal of the $\mathrm{CO}_{2}$ emissions-income relationships Theophile AZOMAHOU, Micheline GOEDHUYS, Phu NGUYEN-VAN, janvier 2010.

2010-04 The signaling role of policy action

Romain BAERISWYL, Camille CORNAND, février 2010.

2010-05 Pro-development growth and international income mobility: evidence world-wide Jalal EL OUARDIGHI, mars 2010.

2010-06 The determinants of scientific research agenda: Why do academic inventors choose to perform patentable versus non-patentable research?

Caroline HUSSLER, Julien PENIN, mars 2010.

2010-07 Adverse Selection, Emission Permits and Optimal Price Differentiation Mourad AFIF, Sandrine SPAETER, mars 2010.

2010-08 The impact of ambiguity on health prevention and insurance Johanna ETNER, Sandrine SPAETER, mars 2010.

2010-09 Equité du plaider coupable : une analyse économétrique dans trois tribunaux de grande instance français.

Lydie ANCELOT, mars 2010.

2010-10 Networks, Irreversibility and Knowledge Creation.

Patrick LLERENA, Muge OZMAN, mars 2010.

2010-11 Les clusters et les réseaux comme fondements de la dynamique d'innovation dans l'industrie biopharmaceutique

Marc Hubert DEPRET, Abelillah HAMDOUCH, avril 2010.

2010-12 Large-scale risks and technological change: What about limited liability? Julien JACOB, Sandrine SPAETER, avril 2010.

2010-13 Innovation and Development. The Evidence from Innovation Surveys

Francesco BOGLIACINO, Giulio PERANI, Mario PIANTA, Stefano SUPINO, avril 2010.

2010-14 Cooperative provision of indivisible public goods

Pierre DEHEZ, juin 2010.

2010-15 Implications de l'imperfection des marchés financiers pour la politique monétaire Meixing DAI, juin 2010. 
La présente liste ne comprend que les Documents de Travail publiés à partir du $1^{\mathrm{er}}$ janvier 2010 . La liste complète peut être donnée sur demande.

This list contains the Working Paper writen after January 2010, 1rst. The complet list is available upon request. 